\title{
Variables Associated with Gestational Anxiety in Primigravidas and Multigravidas
}

\author{
Rafaela de Almeida Schiavo*,1, 2 \\ Orcid.org/0000-0001-7290-3610 \\ Olga Maria Piazentin Rolim Rodrigues ${ }^{3}$ \\ Orcid.org/0000-0002-5332-256X \\ Gimol Benzaquen Perosa ${ }^{4}$ \\ Orcid.org/0000-0002-7825-2537

\begin{abstract}
${ }^{1}$ Universidade Paulista, Bauru, SP, Brasil
${ }^{2}$ Instituto Municipal de Ensino Superior de São Manuel, São Manuel, SP, Brasil

${ }^{3}$ Universidade Estadual Paulista "Júlio de Mesquita Filho", Bauru, SP, Brasil

${ }^{4}$ Universidade Estadual Paulista "Júlio de Mesquita Filho”, Botucatu, SP, Brasil
\end{abstract}

\begin{abstract}
This study aimed to describe and compare anxiety on primigravidae and multiparous in the third quarter, as well as to identify, among sociodemographic variables and of pregnancy, which ones were associated with high anxiety. There were 479 pregnant women participants who responded to an anxiety instrument (STAI) and a questionnaire on sociodemographic variables and about pregnancy. The groups were statistically compared e a logistic regression model was composed to evaluate associations. The results indicated that $36 \%$ of pregnant women presented symptoms of high anxiety on third gestational trimester, with a predominance of the multiparous in relation to the primigravidae. For the multiparous, the highest chance for high anxiety was associated with low income and for the primigravidae to the threat of miscarriage in early pregnancy. For both primigravidae and multiparous, wanting the baby appeared as a protective factor for high anxiety. The expressive percentage of pregnant women with anxiety symptoms justifies the offering of prevention services and promotion of mental health for pregnant women, with a differentiated attention to primigravidae and multiparous.
\end{abstract}

Keywords: Anxiety, pregnant, primigravidae, multiparous.

\section{Variáveis Associadas à Ansiedade Gestacional em Primigestas e Multigestas}

\section{Resumo}

Este estudo teve por objetivo descrever e comparar a ansiedade de primigestas e multigestas, no terceiro trimestre gestacional, bem como identificar, dentre as variáveis sociodemográficas e de gestação, as que

* Mailing address: Rua Quintino Bocaiúva, s/n, Aparecida de São Manuel, São Manuel, SP, Brazil 18650-000 Phone (fax) 2(14) 3841-3766. E-mail: professora.schiavo@gmail.com, olgarolim@fc.unesp.br and gimol@, fmb.unesp.br

Agradecemos a Fundação de Amparo à Pesquisa do Estado de São Paulo (FAPESP); Coordenação de Aperfeiçoamento de Pessoal de Nível Superior (CAPES) pelo auxílio financeiro para execução desse estudo. 
se associaram para alta ansiedade. Participaram 479 gestantes que responderam a um instrumento de ansiedade (IDATE) e um questionário sobre variáveis sociodemográficas e da gestação. Compararamse os grupos estatisticamente e montou-se um modelo de regressão logística para avaliar o peso das associações $(p<0,05)$. Os resultados indicaram que $36 \%$ das gestantes apresentaram sintomas de alta ansiedade no terceiro trimestre gestacional, com um predomínio das multigestas em relação às primigestas. Para as multigestas, a maior chance para alta ansiedade esteve associada à baixa renda e, para as primigestas, à ameaça de aborto no início da gestação. Tanto para primigestas como para multigestas, desejar o bebê apareceu como fator de proteção para alta ansiedade. A expressiva porcentagem de gestantes com sintomas de ansiedade justifica o oferecimento de serviços voltados à prevenção e promoção de saúde mental das gestantes, com atenção diferenciada às primigestas e multigestas.

Palavras-chave: Ansiedade, gravidez, primigesta, multigesta.

\section{Las Variables Asociadas con la Ansiedad Gestacional en el Primigestas y Multigestas}

\section{Resumen}

Este estudio tuvo como objetivo describir y comparar la ansiedad en el primigestas y multigestas en tercer trimestre, y para identificar, entre las variables sociodemográficas y el embarazo, que se asocian a mayor ansiedad. Participaron en 479 mujeres embarazadas que respondieron a un instrumento de ansiedad (STAI) y un cuestionario sobre variables sociodemográficas y el embarazo. Los investigadores compararon los grupos estadísticamente y montaron un modelo de regresión logística para evaluar las asociaciones. Los resultados indicaron que el 36\% de las mujeres embarazadas tenían síntomas altos de ansiedad en tercer trimestre, con un predominio de multigestas en relación con el primigestas. Para multigestas la mayor oportunidad para alta ansiedad se asoció con bajas ingresos y para el primigestas con un aborto involuntario en el embarazo temprano. Ambos primigestas y multigestas quieren el bebé apareció como un factor protector para alta ansiedad. Un porcentaje significativo de mujeres embarazadas con síntomas de ansiedad justifica los servicios dirigidos a la prevención y promoción de la salud mental de las mujeres embarazadas, con una especial atención a las primigestas y multigestas.

Palabras clave: Ansiedad, embarazo, primigestas, multigestas.

Anxiety is part of the process of human development, and can be present in all periods of the life cycle. It is a characteristic that occurs in times of fear, danger or tension. However, in some moments of life, anxiety is more intense than in others. Depending on the period, it is considered to be an expected emotional state during a change of employment, faced with the result of a job application or medical examination, marriage, pregnancy and the birth of a child, among others.

Anxiety in pregnancy is one of the most common psychological changes (Baptista, Baptista, \& Torre, 2006; Faisal-Cury, Araya, Zugaib, \& Menezes, 2010), varying in intensity in different societies and cultures, with its indices being higher than in the puerperium (Agrati et al., 2015; Baptista et al., 2006) for both fathers and mothers (Figueiredo \& Conde, 2011). Due to the negative regulation of placental $11 \beta-H S D 2$, which increases fetal exposure to maternal cortisol (O'Donnell et al., 2012), high levels of anxiety in pregnancy can result in complications and intercurrences such as premature birth and low birth weight (Bener, 2013; Schetter \& Tanner, 2012).

Gestational anxiety is also associated with shorter exclusive breastfeeding (Adedinsewo, Fleming, Steiner, Meaney, \& Girard, 2014; Ystrom, 2012), which may have negative consequences for the mother/baby relationship (Airosa \& Silva, 2013; Nardi, Rodrigues, 
Melchiori, Salgado, \& Tavano, 2015). It may also affect growth and cause delays in childhood development (Beltrami, Moraes, \& Souza, 2013; O’Donnell, Glover, Barker, \& O'Connor, 2014; Schetter \& Tanner, 2012).

Regarding the maternal mental health, gestational anxiety has been associated with gestational depression (Schetter \& Tanner, 2012) and is indicative of puerperal anxiety and depression (Agrati et al., 2015; Coelho, Murray, Royal-Lawson, \& Cooper, 2011; Faisal-Cury et al., 2010) coinciding with the studies of Airosa and Silva (2013) and Nardi et al. (2015) who observed that gestational anxiety left women vulnerable to the emergence of emotional disturbances. However, in the study by Saviani-Zeoti and Petean (2015), elevated levels of gestational anxiety did not present any impairment in the attachment relationship with the fetus.

According to the literature, some of the risk factors for high gestational anxiety are low maternal age, low educational level (Araújo, Pacheco, Pimenta, \& Kac, 2008), low income (Simas, Souza, \& Scorsolini-Comin, 2013) and threat of abortion (Alves, Alves, Ibiapina, Busgaib, \& Costa, 2010). Fonseca-Machado, Alves, Freitas, Monteiro, and Gomes-Sponholz (2014), in an integrative literature review, identified that domestic violence during the pregnancy had negative repercussions on the mental health of pregnant women. In the review carried out for the present article, no references were found for studies that emphasized the protective factors for high anxiety.

Few studies have addressed gestational anxiety in multigravidas and primigravidas and the results are still inconclusive, sometimes associating high anxiety with primigravidas (Alves et al., 2007), or with multigravidas (Lopes, Vivian, Oliveira, Pereira, \& Piccinini, 2012), or presenting no differences between the two groups (Simas et al., 2013). According to Alves et al. (2007), primiparity, even though it is a period of adaptive psychic normality, it is also a critical moment marked by anguish due to the prominence of having to assume a new role, that of being a mother, which can increase anxiety. Due to cultural issues, this new responsibility is often accompanied by guilt and anxiety, with the woman being insecure about whether she will fully correspond to the ideal of mothering spread in Western society, expecting perfect mothers, housewives and wives (Pitilin, Haracemiw, Marcon, \& Pelloso, 2013).

For Simas et al. (2013), primigravidas and multigravidas are equally anxious, however, they present anxiety for different reasons: the primigravidas are more distressed by their inexperience in the task of being a mother while the multigravidas are more ambivalent with the unplanned pregnancy. On the other hand, for Lopes et al. (2012), it is a myth to believe that the experience of motherhood with the first-born would facilitate the relationship with the second child. According to the authors, multigravidas, especially those who are economically vulnerable and have to assume countless costs, experience a silenced social violence, where there is no room for error, anger and sadness, which may justify the high anxiety rates.

In the puerperium, the results are also controversial. In Brazil, Faisal-Cury and Menezes (2006) identified that multiparous women presented higher indices of anxiety than primiparous women. In the study by Verissimo (2010) in Portugal, primiparas were found to have greater anxiety.

In addition to the incipient literature and the inconclusive data regarding the possible mental health problems in primigravidas and multigravidas, some research has been interested in the repercussion that the number of children can have on the quality of life of the couple as well as their relationship with the children (Camarneiro \& Justo, 2012; Pereira, Fonseca, Oliveira, Souza, \& Mello, 2013; Saviani-Zeoti $\&$ Petean, 2015). There are data indicating that primigravidas have higher marital satisfaction, greater preoccupation with the fetus and better perception of their quality of life than multigravidas (Camarneiro \& Justo, 2012). On the other hand, in the study by Pereira et al. (2013), a higher percentage of multiparous 
women breastfed in the first hour after birth than primiparous women.

As can be seen, studies comparing anxiety levels between primigravidas and multigravidas, as well as its associated factors, are still scarce with differing results, possibly due to the samples, evaluation instruments and diverse contexts of investigation. These findings suggest the need for further investigation in order to assist in offering differentiated support services to primiparous and multiparous pregnant women, focused on the control of maternal anxiety in this period of the life cycle. Based on the above considerations, this study had the objective of describing and comparing the anxiety of primigravidas and multigravidas in the third gestational trimester, as well as identifying the sociodemographic and gestational variables associated with high anxiety.

\section{Method}

This was a cross-sectional study that evaluated the sociodemographic characteristics, the perception of motherhood and the anxiety of pregnant women. To compose the sample, locations were selected that concentrated a large number of consultations for the pregnant woman through the Brazilian Nation Health System (Sistema Único de Saúde - SUS), in three medium-sized cities in the state of São Paulo.

\section{Participants}

Between 2010 and 2015, 485 pregnant women in the third trimester that were waiting for prenatal care at the Primary Health Units (PHUs) were invited to participate in the study. Of these, 479 agreed to participate in the study and, while waiting, completed the instruments individually, in an appropriate room. There were 222 primigravidas and 257 multigravidas.

\section{Instruments}

The authors used a single form with 11 questions, five of which were related to sociodemographic data (age, marital status, schooling, family income, number of children), three con- cerned the medical history (health and mental health prior to gestation, health during gestation) and two were related to the pregnancy (threat of abortion of the current pregnancy and previous abortion). The pregnant women were also asked if they and their partners had wanted the baby (or not).

For the assessment of anxiety, the StateTrait Anxiety Inventory (STAI), developed by Spielberger, Gorsuch, and Lushene (1970) and translated and adapted into Portuguese by Biaggio and Natalício (1979/2003), was used. It is an self-application instrument, for youths and adults, composed of two scales that evaluate State anxiety (S-anxiety) and Trait anxiety (T-anxiety). From 20 items, individuals have to evaluate themselves, according to a four-point Likert-type scale.

Regarding its psychometric qualities, its reliability in the test-retest was 0.74 for State anxiety and 0.83 for Trait anxiety. The internal consistency, assessed through Cronbach's Alpha, was 0.88 in relation to female State anxiety and 0.87 for female Trait anxiety (Biaggio \& Natalício, 1979/2003). For the present study, internal consistency was calculated through Cronbach's Alpha for state and trait anxiety in the third trimester. Alphas of 0.67 for State anxiety and 0.63 for Trait anxiety were obtained, indicating that the consistency indices for the Portuguese version of the STAI applied with pregnant women were moderate to good. As the indication of symptoms of high anxiety, the cut-off point used was a score equal to or above the $75^{\text {th }}$ percentile, as previously used in other studies (Perosa, Canavez, Silveira, Padovani, \& Peraçou, 2009; Perosa, Silveira, \& Canavez, 2008).

\section{Data Collection Procedure}

The recruitment of the participants took place in the PHUs of the three cities of São Paulo state. The researcher, the first author of this study, approached all the pregnant women who were in the third trimester and who waited in the waiting room to be attended by the obstetrician and invited them to participate in the study, stat- 
ing that they had to respond to two instruments, and that one would assess their level of anxiety. The pregnant women who agreed to participate, after signing the consent form, completed the Form and the STAI in a room of the health unit reserved for this purpose. For the non-literate pregnant women and those who, for some reason, preferred not to read, the researcher read the inventory questions and filled out the answer sheet of the instrument. All the pregnant women were informed about the result of the STAI soon after its application, the ones that scored for high anxiety were advised to seek specialized clinical psychological care, the researcher gave these women the telephone number and address of the place where they could find this care.

\section{Data Analysis Procedure}

The sociodemographic, clinical and gestational, numerical and categorical variables were binarized and organized in the Statistical Package for the Social Sciences (SPSS, version 21.0, Chicago INc II, USA) database for further data analysis. The criterion to binarize the age was the one proposed by the World Health Organization (WHO, 1986) that defines the ages between 10 and 19 years as adolescence. The STAI was corrected according to the specific norms of the manual and the binarized results, considering the $75^{\text {th }}$ percentile as a marker of high anxiety. The numerical variables (maternal age and number of children) and categorical variables (all dummy type) were analyzed using descriptive statistics (frequency and percentage). Before proceeding to the inferential statistical analysis, the Shapiro-Wilk test was applied to test the normality of the variables. The chi-square test was used to compare the primigravidas and multigravidas regarding the sociodemographic variables related to the clinical and gestational history and high anxiety. To identify possible variables that were predictors of risk or protection for high anxiety, a logistic regression model with all dichotomous variables in a single block was applied for the total sample and, separately, for the primigravidas and multigravidas. The significance level adopted was $p<.05$.

\section{Ethical Procedures}

The project was approved by the Research Ethics Committee of the Botucatu Medical School Universidade Estadual Paulista "Júlio de Mesquita Filho" - UNESP (process No. 41662012) and by the Faculty of Sciences of UNESP Bauru campus (process No. 614/46/01/09). The data collection was authorized by the heads of the three centers that attended the pregnant women in primary care. Data collection only took place after the signing of the consent form that was given to the participants. All 479 participants, after responding to the instruments, awaited correction by the researcher at the application site, which immediately provided the result. Those who scored for high anxiety were referred to specialized professional care locations in their city.

\section{Results}

Primarily, sociodemographic and maternity data will be presented. This will be followed by the trait and state anxiety characteristics among the primigravidas and multigravidas in the third gestational trimester, the factors associated with high anxiety in the third trimester and the factors associated with high anxiety in primigravidas and multigravidas.

From Table 1 it is possible to verify that the multigravidas were significantly older $(p<.001)$, with a mean of 27 years $(S D=5.4)$, while the primigravidas had a mean age of 20 years $(S D=5.5)$. Regarding the number of children, $36.6 \%$ of the multigravidas already had one child, $34.4 \%$ had two and $42.2 \%$, three or more children. The multigravidas also presented lower levels of education $(p=.009)$ and a higher percentage of the mothers $(p=.004)$ and fathers $(p=.049)$ had not wanted the baby when compared to the primigravidas.

Considering the total sample, trait or state, around $36 \%$ of the pregnant women presented high anxiety. In Table 2 it can also be observed that, significantly, a higher percentage of multigravidas presented high anxiety, both trait $(61.8 \%)$ and state $(60.9 \%)$ in relation to the primigravidas. 
Table 1

Comparison between Primigravidas and Multigravidas according to Sociodemographic and Maternity Characteristics $(N=479)$

\begin{tabular}{|c|c|c|c|c|c|c|c|}
\hline \multirow{3}{*}{ Associated Variables } & \multicolumn{4}{|c|}{ Parity } & \multirow[b]{3}{*}{ Total } & \multirow{3}{*}{$\mathrm{X}^{2}$} & \multirow{3}{*}{$p-$ value $^{*}$} \\
\hline & \multicolumn{2}{|c|}{$\begin{array}{c}\text { Primigravidas } \\
\quad n=222\end{array}$} & \multicolumn{2}{|c|}{$\begin{array}{c}\text { Multigravidas } \\
n=257\end{array}$} & & & \\
\hline & $F$ & $\%$ & $F$ & $\%$ & & & \\
\hline Age & & & & & & 107.395 & $<.001$ \\
\hline$\leq 19$ years old & 101 & 88.6 & 13 & 11.4 & $114(24 \%)$ & & \\
\hline$\geq 20$ years old & 121 & 33.2 & 244 & 66.8 & $365(76 \%)$ & & \\
\hline Marital Status & & & & & & 2.674 & .102 \\
\hline Lives with partner & 164 & 44.3 & 206 & 55.7 & $370(77 \%)$ & & \\
\hline Don't live with partner & 58 & 53.2 & 51 & 46.8 & $109(23 \%)$ & & \\
\hline Education & & & & & & 6.479 & .011 \\
\hline$\leq$ nine years old & 84 & 39.8 & 127 & 60.2 & $211(44 \%)$ & & \\
\hline$>$ nine years old & 138 & 51.5 & 130 & 48.5 & $268(56 \%)$ & & \\
\hline Paid Occupation & & & & & & 0.018 & .893 \\
\hline Yes & 73 & 45.9 & 86 & 54.1 & $159(33 \%)$ & & \\
\hline No & 149 & 46.6 & 171 & 53.4 & $320(67 \%)$ & & \\
\hline Family Income & & & & & & 0.628 & .428 \\
\hline$\leq 2$ minimum wages & 206 & 45.9 & 243 & 54.1 & $449(94 \%)$ & & \\
\hline$>2$ minimum wages & 16 & 53.3 & 14 & 46.7 & $30(6.3 \%)$ & & \\
\hline Pre-gestational health & & & & & & 2.737 & .098 \\
\hline Normal & 206 & 47.6 & 227 & 52.4 & $433(90 \%)$ & & \\
\hline A problem & 16 & 34.8 & 30 & 65.2 & $46(10 \%)$ & & \\
\hline Gestational health & & & & & & 1.482 & .223 \\
\hline Normal & 189 & 47.6 & 208 & 52.4 & $397(83 \%)$ & & \\
\hline A problem & 33 & 40.2 & 49 & 59.8 & $82(17 \%)$ & & \\
\hline Threat of abortion & & & & & & 0.267 & .605 \\
\hline Yes & 21 & 42.9 & 28 & 57.1 & $49(10 \%)$ & & \\
\hline No & 201 & 46.7 & 229 & 53.3 & $430(90 \%)$ & & \\
\hline Wanted the baby & & & & & & 8.223 & .004 \\
\hline Yes & 147 & 51.8 & 137 & 48.2 & $284(59 \%)$ & & \\
\hline No & 75 & 38.5 & 120 & 61.5 & $195(41 \%)$ & & \\
\hline Partner wanted the baby & & & & & & 3.892 & .049 \\
\hline Yes & 158 & 49.5 & 161 & 50.5 & $319(67 \%)$ & & \\
\hline No & 64 & 40.0 & 96 & 60.0 & $160(33 \%)$ & & \\
\hline
\end{tabular}

Note. F- frequency; \% - percentage; $\mathrm{X}^{2}$ - Chi-Square.

$* p$-value for the Chi-Square test. 
Table 2

Difference between Primigravidas and Multigravidas in High Trait/State Anxiety $(N=479)$

\begin{tabular}{|c|c|c|c|c|c|c|c|c|}
\hline & \multicolumn{4}{|c|}{ Parity } & & & \multirow{3}{*}{$\mathrm{X}^{2}$} & \multirow{3}{*}{$p-$ value* } \\
\hline & \multicolumn{2}{|c|}{ Primigravidas } & \multicolumn{2}{|c|}{ Multigravidas } & \multicolumn{2}{|c|}{ Total } & & \\
\hline & $F$ & $\%$ & $F$ & $\%$ & $F$ & $\%$ & & \\
\hline Trait anxiety & & & & & & & 7.316 & .007 \\
\hline No high anxiety & 156 & 51.0 & 150 & 49.0 & 306 & 63.9 & & \\
\hline With high anxiety & 66 & 38.2 & 107 & 61.8 & 173 & 36.1 & & \\
\hline Total & 222 & 46.3 & 257 & 53.7 & 479 & 100 & & \\
\hline State anxiety & & & & & & & 5.802 & .016 \\
\hline No high anxiety & 154 & 50.5 & 151 & 49.5 & 305 & 63.7 & & \\
\hline With high anxiety & 68 & 39.1 & 106 & 60.9 & 174 & 36.3 & & \\
\hline Total & 222 & 46.3 & 257 & 53.7 & 479 & 100 & & \\
\hline
\end{tabular}

Note. $F$ - frequency; \% - percentage; $\mathrm{X}^{2}$ - Chi-Square.

* $p$-value for the Chi-Square teste.

Table 3

Associated Factors for Greater and Lesser Chance of High Trait/State Anxiety in the Third Trimester of Gestation $(N=479)$

\begin{tabular}{lcccccr}
\hline & \multicolumn{3}{c}{ Anxiety trait } & \multicolumn{2}{c}{ Anxiety state } \\
\cline { 2 - 7 } & $p$-value* & OR & IC 95\% & $p$-value* & OR & IC 95\% \\
\hline Age & .490 & 1.185 & 0.7321 .921 & .068 & 1.593 & 0.9662 .628 \\
Marital Status & .777 & 1.071 & 0.6671 .719 & .766 & 1.079 & 0.6651 .742 \\
Education & .109 & 1.395 & 0.9292 .093 & .317 & 1.234 & 0.8181 .863 \\
Paid Occupation & .220 & 0.757 & 0.4851 .181 & .629 & 0.896 & 0.5741 .398 \\
Family Income & .247 & 1.736 & 0.6824 .419 & .082 & 2.335 & 0.8986 .069 \\
Pre-gestational health & .266 & 1.464 & 0.7482 .865 & .135 & 1.672 & 0.8523 .280 \\
Gestational health & .520 & 1.187 & 0.7042 .001 & .679 & 0.893 & 0.5211 .529 \\
Threat of abortion & .920 & 1.034 & 0.5391 .983 & .021 & 2.126 & 1.1224 .027 \\
History of abortion & .066 & 1.589 & 0.9702 .600 & .029 & 1.734 & 1.0572 .845 \\
Wanted the baby & .031 & 0.571 & 0.3430 .949 & .003 & 0.455 & 0.2730 .758 \\
Partner wanted the baby & .037 & 0.568 & 0.3340 .967 & .122 & 0.655 & 0.3841 .120 \\
\hline
\end{tabular}

Note. OR - Odds Ratio; IC - Confidence Interval.

* $p$-value for the Logistic Regression.

In the prediction analysis for the total of the sample, it can be observed that no sociodemographic variable showed a significant associa- tion with high trait or state anxiety. However, it was found that the mother and her partner having wanted the baby decreased the chance of ex- 
hibiting high trait anxiety in the third trimester of the gestation. Similarly, the mother having wanted the baby decreased the chance of scoring for high state anxiety, in the third trimester of the gestation. The pregnant women who had a clinical history of a threat of abortion in early pregnancy and previous abortion had a higher chance of presenting high state anxiety (Table 3 ).

The factors associated with high trait and state anxiety in the primigravidas (Table 4) and in multigravidas (Table 5) in the third trimester of gestation are presented below.

In Table 4, it can be seen that for the primigravidas, having wanted the baby appeared as a protective factor, while the threat of abortion increased the chance for high state anxiety by 3.464. Regarding trait anxiety, the partner having wanted the baby reduced the chance of the pregnant woman presenting high anxiety.

Table 4

Associated Factors for Greater and Lesser Chance of High Trait/State Anxiety on Primigravidas in in the Third Trimester of Gestation $(n=222)$

Primigravidas

\begin{tabular}{lcccccc}
\cline { 2 - 7 } & \multicolumn{3}{c}{ Anxiety Trait } & \multicolumn{3}{c}{ Anxiety State } \\
\cline { 2 - 7 } & $p$-value* & OR & IC 95\% & $p$-value* & OR & IC 95\% \\
\hline Age & .933 & 0.970 & 0.4811 .958 & .514 & 1.273 & 0.6172 .626 \\
Marital Status & .504 & 0.779 & 0.3741 .622 & .567 & 1.235 & 0.6002 .543 \\
Education & .734 & 1.129 & 0.5692 .226 & .789 & 1.100 & 0.5492 .204 \\
Paid Occupation & .192 & 0.602 & 0.2811 .290 & .942 & 0.973 & 0.4622 .047 \\
Family Income & .355 & 0.554 & 0.1581 .938 & .757 & 0.816 & 0.2262 .947 \\
Pre-gestational health & .923 & 1.061 & 0.3233 .480 & .703 & 1.253 & 0.3933 .996 \\
Gestational health & .412 & 0.678 & 0.2681 .716 & .381 & 0.662 & 0.2631 .666 \\
Threat of abortion & .136 & 2.164 & 0.7855 .964 & .017 & 3.464 & 1.2459 .640 \\
History of abortion & .196 & 1.842 & 0.7304 .651 & .086 & 2.263 & 0.8915 .749 \\
Wanted the baby & .839 & 0.910 & 0.3652 .267 & .033 & 0.390 & 0.1640 .928 \\
Partner wanted the baby & .020 & 0.322 & 0.1240 .837 & .358 & 0.653 & 0.2631 .620 \\
\hline
\end{tabular}

Note. OR - Odds Ratio; IC - Confidence Interval.

$* p$-value for the Logistic Regression.

With respect to multigravidas, low income increased the chance of having high trait and state anxiety while having wanted the baby decreased the chance, for both types of anxiety (Table 5).

\section{Discussion}

The sociodemographic characteristics of the participants were similar to those of oth- er Brazilian studies evaluating pregnant and puerpera women (Faisal-Cury \& Menezes, 2006; Morais, Lucci, \& Otta, 2013; Beltrami et al., 2013), which permits comparisons between the present study and others. As in other studies (Borges, Santos, Nascimento, Chofakian, \& Gomes-Sponholz, 2016; Conceição \& Fernandes, 2015), a large number of the pregnant women reported not having wanted the pregnancy $(41 \%)$, especially the 
Table 5

Associated Factors for Greater and Lesser Chance of High Trait/State Anxiety on Multigravidas in in the Third Trimester of Gestation $(n=257)$

\begin{tabular}{lcccccc}
\hline & \multicolumn{3}{c}{ Multigravidas } \\
\cline { 2 - 6 } & \multicolumn{3}{c}{ Anxiety Trait } & \multicolumn{3}{c}{ Anxiety State } \\
\cline { 2 - 7 } & $p$-value* & OR & IC 95\% & $p$-value* & OR & IC 95\% \\
\hline Age & .802 & 0.856 & 0.2532 .892 & .137 & 2.641 & 0.7359 .489 \\
Marital Status & .328 & 1.405 & 0.7112 .773 & .758 & 0.898 & 0.4551 .775 \\
Education & .119 & 1.553 & 0.8942 .698 & .276 & 1.355 & 0.7852 .340 \\
Paid Occupation & .761 & 0.914 & 0.5121 .632 & .655 & 0.878 & 0.4951 .557 \\
Family Income & .043 & 5.094 & 1.05024 .704 & .021 & 6.622 & 1.33732 .793 \\
Pre-gestational health & .236 & 1.702 & 0.7064 .104 & .167 & 1.836 & 0.7754 .352 \\
Gestational health & .129 & 1.727 & 0.8533 .496 & .793 & 1.098 & 0.5452 .215 \\
Threat of abortion & .146 & 0.503 & 0.1991 .270 & .360 & 1.493 & 0.6333 .525 \\
History of abortion & .368 & 1.327 & 0.7172 .453 & .162 & 1.538 & 0.8412 .813 \\
Wanted the baby & .007 & 0.397 & 0.2030 .776 & .015 & 0.439 & 0.2260 .850 \\
Partner wanted the baby & .641 & 0.848 & 0.4251 .693 & .303 & 0.698 & 0.3521 .384 \\
\hline
\end{tabular}

Note. OR - Odds Ratio; IC - Confidence Interval.

$* p$-value for the Logistic Regression.

multigravidas. This suggests that, despite the law guaranteeing family planning as a State responsibility, the aim of providing conditions for men and women to access information about contraception (Prates, Abib \& Oliveira, 2008) may not be occurring effectively. For some authors, this is due to the limitation and deficiency in the care infrastructure, the lack of information regarding contraception among women or the resistance of the spouse to seek family planning services (Caetano, 2014; Penaforte et al., 2010; Pitilin et al., 2013).

The multigravidas were older than the primigravidas. It was hoped that because the multigravidas were older, indicating greater experience, knowledge and the ability to anticipate occurrences acquired in raising other children, they would present lower anxiety compared to the primigravidas. However, in this study, as in Lopes et al. (2012) a high- er number of multigravidas presented high anxiety, perhaps associated with their low income and number of children, as will be discussed later.

This study allowed the identification of approximately $36 \%$ of the participants, in the last trimester of gestation, with high trait and state anxiety. This proportion is smaller than that of other national studies, probably due to the cut-off point adopted for high anxiety in this study being higher than in other studies (Baptista et al., 2006; Faisal-Cury \& Menezes, 2006).

The multigravidas also had lower education levels than the primigravidas, possibly due to the multigravidas not being favored by the new educational policies of continuous progression, which started in 1996, responsible for higher levels of education of pregnant women and puerperas in recent studies (Beltrami et al., 2013; Faisal-Cury \& 
Menezes, 2006; Morais et al., 2013). Studies have highlighted that multiparity is associated with a lower degree of maternal education, which is, in turn, reflected in lower wages, lower family income and greater economic vulnerability (Moura, Silva, Gomes, Almeida, \& Evangelista, 2010; Prates et al., 2008; Severinski, Mamula, Severinski, \& Mamula, 2009).

Confirming the positions of Simas et al. (2013), the percentage of pregnant women with high anxiety, as well as sociodemographic, clinical and gestational risk factors, differed in both groups: for the multigravidas low-income appeared to be a risk factor for high anxiety (trait and state), while for the primigravidas it was the threat of abortion in early pregnancy (state).

As $42.2 \%$ of the multigravidas had more than three children, the arrival of one more child, especially for the low-income multigravidas, may have led to a new reconfiguration of the family system, with more responsibilities and possible losses in their perspective for the future, financial difficulties and reduced quality of life, generating uncertainties and anxiety (Borges, Ferreira, Mariutti, \& Almeida, 2011; Prates et al., 2008; Simas et al., 2013). In the study by Pitilin et al. (2013), with multiparas of four or more children, SUS users, it was observed that economic vulnerability was not limited to income deprivation, but also interfered with the possibility of obtaining quality work with adequate remuneration, with access to public services and with the dynamics of family life.

Thus, financial difficulties may have increased the tension in the multigravidas faced with the birth of a new child, while the possibility of fetal loss increased the chance of high state anxiety in the primigravidas. Often, the threat of abortion is a condition with unknown pathophysiology that requires several types of intervention that, on one hand, seek to prevent fetal loss and, on the other, increase the sensation of unpredictability and anxiety (Alves et al., 2010).
In both the primigravidas and multigravidas, the history of abortion significantly increased the chance of high anxiety (state), possibly because this experience causes pregnant women to experience the new pregnancy with ambivalent feelings of attachment to the baby, as well as insecurity and fear (Freire \& Chatelard, 2009). In the study by Fernandes et al. (2012), both women who spontaneously aborted and those who had provoked an abortion presented anxiety with a new pregnancy associated with fear of another abortion.

While the possibility of losing the child appeared as a risk factor, having wanted the child was associated with less chance of primigravidas and multigravidas presenting symptoms of high anxiety (trace and state). For Pitilin et al. (2013), most of the time, even if the pregnancy was unplanned and women believe they have become pregnant at the wrong time, the initial anguish and anxiety become feelings of resignation, adaptation and, during the pregnancy, they start to want the baby. In some studies, women who did not plan the pregnancy due to financial and marital difficulties had a belief that the baby came to restore the family relationship, including the conjugal one, and the desire for the child became a satisfactory, even saving experience, increasing their self-esteem and protecting them from emotional problems (Moura et al., 2010; Prietsch, González-Chica, Cesar, \& MendozaSassi, 2011; Simas et al., 2013).

The partner wanting the baby decreased the odds for high trait anxiety in the primigravidas, showing that the desire for a child and possible paternal involvement during the pregnancy may have attenuated the uncertainties regarding the care, especially for the primiparas. According to Simas et al. (2013), when the partner accepts the pregnancy and wants to be a father, he becomes more involved in the process, takes responsibility for the preparations for the arrival of the baby with the pregnant woman, offers emotional support, tries to make contact 
with the baby and listens to the concerns and desires of the women, constituting an important social support.

The present study contributed with advances in this area of research, since it compared the anxiety of primigravidas and multigravidas in the third gestational trimester, and identified, among the sociodemographic and gestational variables, those that were associated with high anxiety in each group. This can allow socio-educative measures to be developed from the data identified with greater attention to the emotional health of pregnant women, mainly low-income multigravidas and primigravidas with the threat of abortion in early pregnancy.

\section{Final Considerations}

The results obtained bring advances to the knowledge in the area, however, it is important to consider some limitations of this study that could help in the planning of new investigations. The first limitation refers to the instrument used to measure anxiety, the STAI, which was also used in other studies to identify levels of anxiety at the end of gestation (Agrati et al., 2015; Araújo et al., 2008; Baptista et al., 2006; O'Donnell et al., 2012; Roos, Faure, Louchner, Vythilingum, $\&$ Stein, 2013). Although the reliability calculated for this study through Cronbach's alpha showed moderate to good indices, the STAI is not a specific instrument for pregnant women, since some symptoms evaluated as anxiety could be characteristics expected during pregnancy. It is recommended that further investigations be conducted to identify the best instrument to measure anxiety in pregnant women, or to develop an instrument specific for this population.

Another possible limitation of the study may have been the fact that all the variables, including the continuous ones, such as age and income, were binarized and, if considered in their continuous form, they would possibly allow a more accurate analysis of anxiety in the different age and socioeconomic groups, in the logistic regression. Also, the fact that the sample was not probabilistic, but constituted by convenience, limits the generalization of the results. It is recommended that, in new investigations, in addition to not binarizing the variables, the subjects should be randomized, increasing the generality of the results.

Despite the limitations, the present study identified high anxiety in $36 \%$ of the pregnant women using the SUS, in the third trimester of pregnancy, mainly among the multigravidas. The already proven association of gestational anxiety with obstetric complications and puerperal depression, as well as with damage that can affect childhood growth and development, indicate the need for professionals that work in prenatal care to pay special attention to the emotional health of the pregnant women.

The study also reinforces that the risk factors for high anxiety are different in primigravidas and multigravidas, justifying the provision of differentiated care for women pregnant for the first time and for those that have been through previous pregnancies. In the case of the primigravidas, experiencing a threat of abortion in early pregnancy appeared as the main variable predicting high anxiety in the third trimester, which indicates the importance of providing maximum information, along with psychological support, at that moment. Often, there are no reasons to justify the threat of abortion (Alves et al., 2010), which leads many women to perceive it as an individual fault, associated with feelings of guilt and fantasies of "a deserved punishment", relevant aspects to be considered in the actions of psychological health care.

The feelings and fantasies of primigravidas need to be addressed from the moment the threat of abortion occurred to prevent the chronification of the pregnant woman's emotional state, which may ultimately negatively influence both the maternal mental health and the birth, as well as the physical and emotional health of the baby. However, studies are still needed to verify what type of care, individual or group, can more effectively prevent the aggravation of anxiety at the end of gestation.

With regard to the multigravidas, a high percentage had not wanted the baby $(60 \%)$ and high anxiety was associated with low income, a 
structural variable in which health professionals cannot act, with public policies in the care of these women, therefore, being relevant, in order to favor social-assistance, education and vocational resources. In addition, it is possible to act preventively by investing in programs that promote more efficient and effective family planning for families using the public health system. Advances in contraception have enabled greater decision-making power for couples and the woman herself, with the possibility of choosing when to have a child becoming a decisive factor for a healthy pregnancy and maternity/paternity.

It is also hoped that these results can help in the development of new studies and provide support for policies aimed at pregnant users of public services. The intention is to provide healthcare that goes beyond the biomedical scope and takes into account emotional and social vulnerabilities from the development of approaches that ultimately improve the quality of life of this population.

\section{References}

Adedinsewo, D. A., Fleming, A. S., Steiner, M., Meaney, M. J., \& Girard, A. W. (2014). Maternal anxiety and breastfeeding: Findings from the MAVAN (Maternal Adversity, Vulnerability and Neurodevelopment) study. Journal Human Lactation, 30(1), 102-109. doi: $10.1177 / 0890334413504244$

Agrati, D., Browne, D., Jonas, W., Meaney, M., Atkinson, L., Steiner, M., \& Fleming, A. S. (2015). Maternal anxiety from pregnancy to 2 years postpartum: Transactional patterns of maternal early adversity and child temperament. Archives of Women's Mental Health, 18(5), 693-705. doi: 10.1007/s00737-014-0491-y

Airosa, S., \& Silva, I. (2013). Associação entre vinculação, ansiedade, depressão, estresse e suporte social na maternidade. Psicologia, Saúde e Doença, 14(1), 64-77. Retrieved from http:// www.scielo.mec.pt/pdf/psd/v14n1/v14n1a05. pdf

Alves, A. M., Gonçalves, C. S. F., Martins, M. A., Silva, S. T., Auwerter, T. C., \& Zagonel, I. P. S. (2007). A enfermagem e puérperas primigestas: Desvendando o processo de transição ao papel materno. Cogitare Enfermagem, 12(4), 416-427. Retrieved from revistas.ufpr.br/cogitare/article/ download/10063/6918

Alves, J. A. G., Alves, N. G., Ibiapina, F. L. P., Busgaib, R. P. S., \& Costa, F. S. (2010). Ameaça de aborto: Conduta baseada em evidências. Femina, 38(2), 111-115. Retrieved from http://files. bvs.br/upload/S/0100-7254/2010/v38n2/a010. pdf

Araújo, D. M. R., Pacheco, A. H. R. N., Pimenta, A. M., \& Kac, G. (2008). Prevalência e fatores associados a sintomas de ansiedade em uma coorte de gestantes atendidas em um centro de saúde do município do Rio de Janeiro. Revista Brasileira de Saúde Materno Infantil, 8(3), 333-340. doi: 10.1590/S1519-38292008000300013

Baptista, M. N., Baptista, A. S. D., \& Torres, E. C. R. (2006). Associação entre suporte social, depressão e ansiedade em gestantes. PSIC. Revista de Psicologia da Vetor Editora, 7(1), 39-48. Retrieved from http://pepsic.bvsalud.org/pdf/psic/ v7n1/v7n1a06.pdf

Beltrami, L., Moraes, A. G., \& Souza, A. P. R. A. (2013). Ansiedade materna puerperal e risco para o desenvolvimento infantil. Distúrbios da Comunicação, 25(2), 229-239. Retrieved from http://revistas.pucsp.br/index.php/dic/article/ view/16476/12373

Bener, A. (2013). Psychological distress among mothers of preterm infants and associated factors: A neglected public health problem. Revista Brasileira de Psiquiatria, 35(3), 231-236. doi: 10.1590/1516-4446-2012-0821

Biaggio, A., \& Natalício, L. (2003). Inventário de ansiedade traço-estado - IDATE. Rio de Janeiro, RJ: Centro de Psicologia Aplicada. (Original work published in 1979)

Borges, A. L. V., Santos, O. A, Nascimento, N. C., Chofakian, C. B. N., \& Gomes-Sponholz, F. A. (2016). Preparo pré-concepcional entre mulheres brasileiras e a relação com o planejamento da gravidez. Revista da Escola de Enfermagem da USP, 50(2), 208-216. doi: 10.1590/S0080623420160000200005

Borges, D. A., Ferreira, F. R., Mariutti, M. G., \& Almeida, D. A. (2011). A depressão na gestação: Uma revisão bibliográfica. Revista de Iniciação Científica da Libertas, 1(1), 85-99. Retrieved from http://www.libertas.edu.br/revistalibertas/ revistalibertas 1/artigo6.pdf 
Conceição, S. P., \& Fernandes, R. A. Q. (2015). Influência da gravidez não planejada no tempo de aleitamento materno. Escola Anna Nery, 19(4), 600-605. doi: 10.5935/1414-8145.20150080

Camarneiro, A. P. F., \& Justo, J. M. R. M. (2012). Efeito do número de filhos na satisfação conjugal e na vinculação pré-natal materna e paterna. International Journal of Developmental and Educational Psychology, 1(1), 19-28. Retrieved from http://infad.eu/RevistaINFAD/wp-content/ uploads/2013/02/INFAD_010124_19-28.pdf

Caetano, A. J. (2014). Esterilização cirúrgica feminina no Brasil, 2000 a 2006: Aderência à lei de planejamento familiar e demanda frustrada. Revista Brasileira de Estudos de População, 31(2), 309331. doi: 10.1590/S0102-30982014000200005

Coelho, H. F., Murray, L., Royal-Lawson, M., \& Cooper, P. J. (2011). Antenatal anxiety disorder as a predictor of postnatal depression: A longitudinal study. Journal of Affective Disorders, 129(1-3), 348-353. doi: 10.1016/j.jad.2010.08.002

Faisal-Cury, A., Araya, R., Zugaib, M., \& Menezes, P. R. (2010). Common mental disorders during pregnancy and adverse obstetric outcomes. Journal of Psychosomatic Obstetrics \& Gynecology, 31(4), 22-235. doi: 10.3109/0167482X.2010.512404

Faisal-Cury, A., \& Menezes, P. R. (2006). Ansiedade no puerpério: Prevalência e fatores de risco. Revista Brasileira de Ginecolologia e $\mathrm{Ob}$ stetrícia, 28(3), 171-178. doi: 10.1590/S010072032006000300006

Fernandes, D. L., Albuquerque, N. L. A., Melo, E. A., Silva, R. B., Vasconcelos, E. M. R., \& Leite, H. P. O. (2012). Percepção de um grupo de gestantes detentoras de história de aborto em gestação anterior. Revista de Atenção à Saúde, 10(32), 47-53. doi: 10.13037/rbcs.vol10n32.1592

Figueiredo, B., \& Conde, A. (2011). Anxiety and depression in women and men from early pregnancy to 3-months postpartum. Archives of Women's Mental Health, 14(3), 247-55. doi: 10.1007/ s00737-011-0217-3

Fonseca-Machado, M. O., Alves, L. C., Freitas, P. S., Monteiro, J. C. S., \& Gomes-Sponholz, F. (2014). Mental health of women who suffer intimate partner violence during pregnancy. Investigación y Educación em Enfermaría, 32(2), 291 305. doi: 10.1590/S0120-53072014000200012
Freire, T. C. G., \& Chatelard, D. S. (2009). O aborto é uma dor narcísica irreparável? Revista Mal Estar e Subjetividade, 9(3), 1007-1022. Retrieved from http://pepsic.bvsalud.org/pdf/malestar/ v9n3/12.pdf

Lopes, R. C. S., Vivian, A. G., Oliveira, D. S., Pereira, C. R. R., \& Piccinini, C. A. (2012). Desafios para a maternidade decorrentes da gestação e do nascimento do segundo filho. In C. A. Piccinini \& P. Alvarenga (Eds.), Maternidade e paternidade: A parentalidade em diferentes contextos (pp. 295-318). São Paulo, SP: Casa do Psicólogo.

Moura, E. R. F., Silva, R. M., Gomes, A. M. A., Almeida, P. C., \& Evangelista, D. R. (2010). Perfil demográfico e de saúde reprodutiva de mulheres atendidas em planejamento familiar no interior do Ceará. Revista Baiana de Saúde Pública, 34(1), 119-133. Retrieved from http:// inseer.ibict.br/rbsp/index.php/rbsp/article/viewFile/22/22

Morais, M. L. S., Lucci, T. K., \& Otta, E. (2013). Postpartum depression and child development in first year of life. Estudos de Psicologia (Campinas), 30(1), 7-17. doi: 10.1590/S0103166X2013000100002

Nardi, C. G. A., Rodrigues, O. M. P. R., Melchiori, L. E., Salgado, M. H., \& Tavano, L. D'. (2015). Bebês com sequência de Pierre Robim: Saúde mental materna e interação mãe-bebê. Estudos de Psicologia (Campinas), 32(1), 129-140. doi: 10.1590/0103-166X2015000100012

O’Donnell, K. J., Glover, V., Barker, E. D., \& O'Connor, T. G. (2014). The persisting effect of maternal mood in pregnancy on childhood psychopathology. Development and Psychopathology, 26(2), 393-403. doi: 10.1017/ S0954579414000029

O’Donnell, K. J., Jensen, A. B., Freeman, L., Khalife, N., O’Connor, T. G., \& Glover, V. (2012). Maternal prenatal anxiety and downregulation of placental 11beta-HSD2. Psychoneuroendocrinology, 37(6), 818-826. doi: 10.1016/j. psyneuen.2011.09.014

Penaforte, M. C. L. F., Silva, L. R., Esteves, A. P. V. S., Silva, R. F., Santos, I. M. M., \& Silva, M. D. B. (2010). Conhecimento, uso e escolha dos métodos contraceptivos por um grupo de mulheres de uma unidade básica de saúde em Teresópolis, RJ. Cogitare Enfermagem, 15(1), 124-130. 
Retrieved from http://revistas.ufpr.br/cogitare/ article/viewFile/17183/11318

Pereira, C. R. V. R., Fonseca, V. M., Oliveira, M. I. C., Souza, I. E. O., \& Mello, R. R. (2013). Avaliação de fatores que interferem na amamentação na primeira hora de vida. Revista Brasileira de Epidemiologia, 16(2), 525-534. doi: 10.1590/ S1415-790X2013000200026

Perosa, G. B., Canavez, I. C., Silveira, F. C. P., Padovani, F. H. P., \& Peraçou, J. C. (2009). Sintomas depressivos e ansiosos em mães de recém-nascidos com e sem malformações. Revista Brasileira de Ginecologia e Obstetrícia, 31(9), 433-439. doi: 10.1590/S0100-72032009000900003

Perosa, G. B., Silveira, F. C. P., \& Canavez, I. C. (2008). Ansiedade e depressão de mães de recém-nascidos com malformações visíveis. Psicologia: Teoria e Pesquisa, 24(1), 29-35. doi: 10.1590/S0102-37722008000100004

Pitilin, E. B., Harecemiw, A., Marcon, S. S., \& Pelloso, S. M. (2013). Family support in the everyday life of multiparous women. Revista Gaúcha de Enfermagem, 34(4), 14-20. doi: 10.1590/S198314472013000400002

Prates, C. B., Abib, G. M. C., \& Oliveira, D. L. L. C. (2008). Poder de gênero, pobreza e anticoncepção vivencia de multíparas. Revista Gaúcha de Enfermagem, 29(4), 604-611. Retrieved from http://www.lume.ufrgs.br/bitstream/handle/10183/23610/000681435.pdf?sequence $=1$

Prietsch, S. O. M., González-Chica, D. A., Cesar, J. A., \& Mendoza-Sassi, R. A. (2011). Gravidez não planejada no extremo Sul do Brasil: Prevalência e fatores associados. Caderno de Saúde Pública, 27(10), 1906-1916. doi: 10.1590/ S0102-311X2011001000004

Roos, A., Faure, S., Louchner, C., Vythilingum, B., \& Stein, D. J. (2013). Predictors of distress and anxiety during pregnancy. African Journal of Psychiatry, 16(2), 118-122. doi: 10.4314/ajpsy. v16i2.15

Saviani-Zeoti, F., \& Petean, E. B. L. (2015). Apego materno-fetal, ansiedade e depressão em gestantes com gravidez normal e de risco: Estudo comparativo. Estudos de Psicologia (Campinas), 32(4), 675-683. doi: 10.1590/0103166X2015000400010

Schetter, C. D., \& Tanner, L. (2012). Anxiety, depression and stress in pregnancy: Implications for mother, children, research, and practice. Current Opinion in Psychiatry, 25(2), 141-148. doi: 10.1097/YCO.0b013e3283503680

Severinski, N. S., Mamula, O., Severinski, S. K., \& Mamula, M. (2009). Maternal and fetal outcomes in grand multiparous women. International Federation of Gynecology and Obstetrics, 107(1), 63-64. doi: 10.1016/j.ijgo.2009.05.011

Simas, F. B., Souza, L. V., \& Scorsolini-Comim, F. (2013). Significados da gravidez e da maternidade: Discursos de primíparas e multíparas. Revista Psicologia: Teoria e Prática, 15(1), 19-34. Retrieved from http://pepsic.bvsalud.org/pdf/ ptp/v15n1/02.pdf

Spielberger, C. D., Gorsuch, R. L., \& Lushene, R. E. (1970). The State-Trait Anxiety Inventory (Test Manual). Palo Alto, CA: Consulting Psychologists Press.

Veríssimo, S. M. A. C. (2010). Relações entre ansiedade estado e ansiedade traço, sintomas depressivos e sensibilidade ao estresse em puérperas (Master thesis). Universidade Lusófona de $\mathrm{Hu}-$ manidades e Tecnologias, Lisboa.

World Health Organization. (1986). Young People's Health - A Challenge for Society. Report of a WHO Study Group on Young People and Health for All (Technical Report Series 731). Geneva: Author.

Ystrom E (2012) Breastfeeding cessation and symptoms of anxiety and depression: A longitudinal cohort study. BMC Pregnancy Childbirth, 12(36), 1-6. doi: 10.1186/1471-2393-12-36

Received: 19/12/2016

$1^{\text {st }}$ revision: $28 / 03 / 2017$

$2^{\text {nd }}$ revision: $25 / 08 / 2017$

$3^{\text {rd }}$ revision: $29 / 11 / 2017$

$4^{\text {th }}$ revision: $04 / 01 / 2018$

Accepted: 02/03/2018

(c) B) The Author(s), 2018. Open Access. This article is distributed under the terms of the Creative Commons Attribution 4.0 International License (http://creativecommons.org/licenses/by/4.0/), which permits unrestricted use, distribution, and reproduction in any medium, provided you give appropriate credit to the original author(s) and the source, provide a link to the Creative Commons license, and indicate if changes were made. 